\title{
Associated factors to empyema in post-traumatic hemotorax
}

\section{Fatores associados ao empiema em pacientes com hemotórax retido pós- traumático}

Mario Pastore Neto; ; Vivian Resende, TCBC-MG²; Carla Jorge Machado3\%; Emanuelle Maria Sávio de Abreu'; João Baptista de Rezende Neto4; Marcelo Dias Sanches

\section{A B S T T R A C T}

\begin{abstract}
Objective: to analyze the associated factors with empyema in patients with post-traumatic retained hemothorax. Methods: prospective observational study. Data were collected in patients undergoing PD during emergency duty. Variables analyzed were age, sex, mechanism of injury, side of the chest injury, intrathoracic complications of RH, laparotomy, specific injuries, rib fractures, trauma scores, days to diagnosis, diagnostic method of $\mathrm{RH}$, primary indication of $\mathrm{PD}$, initial volume drained, length of the first tube removal, surgical procedure. Cumulative incidence of empyema, pneumonia and pulmonary contusion and the proportion of patients with empyema or without empyema in each category of each variable analyzed were obtained. Results: the cumulative incidence of PD among trauma patients was $1.83 \%$ and the RH among those with PD was $10.63 \%$. There were 20 cases of empyema (32.8\%). Most were male in the age from 20 to 29, victims of injury by firearm on the left side of the thorax. The incidence of empyema in patients with injury by firearms was lower compared to those with stab wound or blunt trauma; higher among those with drained volume between 300 and $599 \mathrm{ml}$. The median hospital lenght of stay was higher among those with empyema. Conclusion: the incidence of PD was $1.83 \%$ and $\mathrm{RH}$ was $10.63 \%$, these results are consistent with the low severity of the patients involved in this study and consistent with the literature. The incidence of empyema proved to be negatively associated with the occurrence of injury by firearms and positively associated with a drained volume between 300 and 599 ml, compared with lower or higher volumes.
\end{abstract}

Key words: Empyema. Thoracic Injuries. Thorax. Drainage. Hemothorax.

\section{INTRODUCTION}

T horacic trauma is the main cause of mortality in all age groups. This type of trauma has increased around the world ${ }^{1}$. Thoracic injuries are still the second leading cause of mortality due to trauma, corresponding to $20 \%$ to $25 \%$ of deaths ${ }^{2,3}$. Blunt trauma due to automobile accidents corresponds to $70 \%$ to $80 \%$ of all thoracic injuries in the United States ${ }^{2,4}$ and deaths occur in $25 \%$ of the cases ${ }^{3}$. When the mechanism of injury is penetrating, only $40 \%$ of the cases are chest injuries ${ }^{2-4}$.

Most of the traumatic thoracic injuries are treated with pleural drainage (PD), a simple procedure performed by the physician during the initial care approach ${ }^{2}$. When the diagnosis is hemothorax, $85 \%$ to $90 \%$ are satisfactorily treated by PD without complications ${ }^{5}$. The permanence of the drain is determined by lung expansion, which in ideal conditions of treatment, usually occurs in the early days after drainage ${ }^{5}$. Fluid accumulation in the pleural cavity, sometimes, can be identified on imaging, after removing the drain or even when the drain remains in place.This finding has been recognized as residual or retained hemothorax (RH). However, this definition is still not uniform in the medical literature ${ }^{6}$.

Less invasive procedures have been early indicated for treatment of $\mathrm{RH}^{7-12}$. The main goal of the early treatment is to avoid the $\mathrm{RH}$ progression to other complications, especially to empyema, one of the most severe complication which frequently requires a complex approach for treatment ${ }^{5,12,13}$. The $\mathrm{RH}$ is the main predisposing factor for post-traumatic empyema and the incidence varies from $4 \%$ to $20 \%$, $7,13,14$.

The phase of the empyema determines the treatment's modality. Less invasive treatments can be indicated for the earliest phase. The purulent phase is the most complicated and usually requires Eloesser's pleurostomy ${ }^{15,16}$. Other recommended treatment modalities range from conservative treatment, involving only observation, to guided thoracic puncture, redrainage, intrapleural injection of fibrinolytic agents, thoracoscopy (VATS) and thoracotomy with pulmonar decortication 5,8,17. After these treatments the prognosis of the empyema tends

1. Hospital Risoleta Tolentino Neves, Fundep/UFMG; 2. Departamento de Cirurgia da Faculdade de Medicina da UFMG; 3. Departamento de Medicina Preventiva e Social da Faculdade de Medicina da UFMG; 4. Department of Surgery at the University of Toronto - St. Michael's Hospital - Canada. 
to be better because they are performed in exudative and fibrinopurulent stage. However, in the purulent stage, thoracoscopy and open pulmonary decortication have less chance of success.

The literature also highlights selected factors associated with the presence of empyema such as age, mechanisms of trauma (blunt or penetrating), side of the thoracic injury, exploratory laparotomy, severity of the patient, time and the $\mathrm{RH}$ diagnostic method, primary indication for PD, drained volume, permanence of the drain, need of redrainage, length of stay and surgical procedures ${ }^{18,19}$. It is generally agreed that aseptic techniques of PD and complete evacuation of RH are necessary to avoid complications. According to the clinical situation and appearance of the effusion on radiography or computed tomography, $\mathrm{RH}$ can be observed after drainage, depending of the pleural absorptive capacity 8,17,20,21.

Over a period of three years, this study analyzes the associated factors with empyema in patients with posttraumatic $\mathrm{RH}$ in one reference hospital for trauma in Belo Horizonte, Minas Gerais.

\section{METHODS}

This is an observational prospective study of patients admitted in the Risoleta Tolentino Neves (HRTN) Hospital. This work was approved by the Hospital Research Center's Board (Protocol number 01/2012).

Data were collected from 21 November 2009 to 07 March 2013 and stored in particular data collection form. All patients underwent to pleural drainage in the HRTN by the trauma team during emergency duty. The PD was held in water seal in the operating room or the emergency room, according to hospital protocol.

For the total number of trauma care in the period of the study an estimate was made based on the information generated by the MV2000®, management software and electronic registration records. For the number of PD, the Collector $\circledast$, trauma registry software HRTN, deployed since 2009, provided information for the years 2011, 2012 and 2013. Further information about the Collector ${ }^{\circledR}$ are available in the literature ${ }^{22}$. It was considered that the average monthly drainage from January 2011 to March 2013 could be extrapolated for the months of November 2009 to December 2011.

The study included multiple patients victims of blunt or penetrating trauma diagnosed with $\mathrm{RH}$; with hemodynamic stability at admission; Revised Trauma Score (RTS) greater than seven and Injurity Severity Score (ISS) less than 25. Patients aged less than 15 years and those who died due to related injuries, without the possibility of monitoring were excluded. Patients submitted to PD who did not develop $\mathrm{RH}$ also did not take part of this study, as well as those with empyema not related to $\mathrm{RH}$. The imaging methods were radiography and computed tomography scan.
To calculate the sample size, the percentage found in the literature equal to $26.8 \%$ was used as a starting point relative to patients with retained hemothorax that developed empyema ${ }^{17}$. Since August 2012 the use of antibiotics has been routinely used in all patients with hemothorax in our institution, then we decided to use a lower percentage (20\%) of cases. Thus, there was obtained a sample of 61 patients, given a margin of error of $10 \%$ and $95 \%$ of confidence level.

The variables analyzed were: age (continuous in years and stratified in 15-20; 20-29; 30-39; 40 and over 40); gender; mechanism of injury (blunt trauma, stab wound, injury by firearm); the side of the thoracic injury (right, left, right and left); intrathoracic complications associated with RH (empyema, pneumonia, other); laparotomy (yes, no); specific lesions (extrathoracic complications; diaphragm injury, other injuries); fracture of the ribs (number of fractures count); trauma indices (RTS, ISS; TRISS - Trauma and Injury Severity Score); time in days to diagnosis (continuous); diagnostic method of HR (radiography, computed tomography scan); primary indication for PD (hemopneumothorax; pneumothorax, hemothorax); drained initial volume (less than $300 \mathrm{ml}, 300$ $599 \mathrm{ml}, 600 \mathrm{ml}$ or higher); days of the first tube removal (continuous); surgical procedure (yes/no, based on the following inclusion criteria: thoracotomy, thoracoscopy, pleurostomy and decortication).

The cumulative incidence of empyema, pneumonia and pulmonary contusion among patients with $\mathrm{RH}$ was obtained in the study period. Then it was calculated the proportion of patients who developed or not empyema in each category of each variable analyzed. Afterwards the association of each variable with empyema was evaluated.

Pearson's chi-square was used for comparison of categorical data and Fisher's exact when $n<5$. The MannWhitney test (nonparametric test to compare median) was used to compare the count or continuous variables. Mean was not used in any of the count or continuous variables, once the distributions of these variables after been evaluated by Shapiro-Wilk test for skewness and kurtosis did not reveal normality in a level of significance of $5 \%$. The significance level for analysis of associations and difference in medians was $5 \%$.

\section{RESULTS}

Of 31.406 patients seen between November 2009 and March 2013 on HRTN, there were 574 thoracic drainages, of which 61 developed into HR.

The cumulative incidence of PD among patients victims of trauma was $1.83 \%(574 / 31.406)$ and the $\mathrm{RH}$ among those with pleural drainage was $10.63 \%$ (61/574). Thirty three infectious pleuropulmonary complications were observed in 24 patients. There were 20 cases of empyema, 
ten cases of pneumonia, and three cases of infected lung injury, corresponding to $32.8 \% ; 16.4 \%$ and $4.9 \%$ respectively, in the 61 patients with $\mathrm{RH}$.

The median age of the patients was 30 years, most were male between 20 and 29 years old, victims of firearms injuries on the right side of the thorax. Laparotomy was performed in seven patients. Diaphragm injury occurred in 10 patients and extrathoracic complications in 32 . The median for RTS was 7.84, ISS 9.0 and TRISS 0.99. The median time for the diagnosis of HR was four days, ranging from 1 to 38 days. Radiography was the most commonly diagnostic method and hemopneumothorax occurred in 39 patients. The initial volume drained ranged from $300 \mathrm{ml}$ to $599 \mathrm{ml}$ in 35 patients. The median time to remove the first thoracic drain was five days, ranging from zero to 19 days. The median hospital lengh of stay was 10 days, ranging from two to 42 days. Observation, without major surgical procedure (only the initial drainage), was performed in 38 patients (Table 1).

When the stratification of the sample was made by the presence of empyema, there was a higher incidence for: age above 39 years; men; stab wound; injury on the left side of the thorax; patients with extrathoracic complications; patients who did radiography; hemothorax as primary indication for drainage; initial volume drained from 300 to $599 \mathrm{ml}$ and those submitted to surgical procedure (Table 2).

The incidence of empyema in patients with injury by firearm was significantly lower compared to those with stab wound or blunt trauma ( $p=0.008$ ); It was higher among those with volume drained between 300 and $599 \mathrm{ml}$ compared to those with lower or higher volume ( $p=0.030)$. The median hospital length of stay was significantly higher among those with empyema compared to those without empyema $(p=0.001)$.

\section{DISCUSSION}

This study addressed the evolution of posttraumatic RH in 61 patients among the 574 patients with PD between 2009 and 2013. The cumulative 10.5\% incidence of $\mathrm{RH}$ was consistent with other reports in the literature, where the incidence ranges from $4 \%$ to $20 \%{ }^{7,9,17}$.

The trauma indices were consistent with low severity of the patients. Twenty-four patients had intrathoracic infectious pleuropulmonary complications resulting from $\mathrm{RH}$ - empyema, pneumonia and infected lung injury. Previous studies indicate incidences ranging from 3\% to $27 \%$ for these complicações $11,14,23,24$. In this work the incidence was $32.8 \%$, $16.4 \%$, and $4.9 \%$ for empyema, pneumonia and infected pulmonary contusion, respectively. Empyema demands surgical treatment in some cases, being one intrathoracic complication with serious damage for patients ${ }^{19}$.

Patients with penetrating trauma by firearms had significantly lower risk of empyema compared to those with penetrating trauma with knives and blunt trauma. The literature tends to high quote the penetrating mechanism as a risk factor for empyema, but this is controversial and the reasons are not objectively clarified $3,4,12,16$. Another study in Brazil has found similar results to this work regarding the incidence of empyema according to the mechanism of trau$\mathrm{ma}^{19}$. In this work, the finding may be explained by the patient's age effect, once among the 33 patients with penetrating trauma by firearms, only two were older than 40 years (6\%), as opposed to 13 among the remaining 28 with penetrating trauma by knife or blunt trauma (46.4\%) (data not shown). This fact means that, in the present study, patients with different trauma of those by firearms were older, with higher incidence of empyema (compared to the other age groups) among those over 40 years. Age is a risk factor in post-traumatic pleural empyema, because elderly patients have less cardiovascular and respiratory physiological reserves and more associated chronic diseases with propensity to retain pulmonar secretions ${ }^{19}$. There was a higher incidence of empyema when the injury was on the left side of the thorax, but without statistical significance. Evidence indicates that the rib fractures on the left side would be more associated with empyema ${ }^{8,12,17}$, corroborating with the findings of this study.

The diagnostic method most used for $\mathrm{RH}$ was radiography, performed in 53 patients (86.9\% of total), held on the occasion of the chest tube removal. Perhaps this is the reason for underestimated diagnosis of $\mathrm{RH}$ and empyema, considering that CT scan was used to study the characteristics of the collection only after this one be seen on radiography, or during the initial phase of the trauma care. Another interesting factor is that chest radiography, in some cases of trauma, consists only of the anteroposterior position, a fact that reduces the possibility of diagnosis of small amounts of liquid which is better seen in the lateral view. If the CT scan had been used in all patients, certainly the amount of fluid in the pleural cavity would be higher, since it is known that CT is an excellent imaging method for rapid diagnosis, especially for evaluation of hemodynamically stable patients with blunt abdominal trau$m a^{25}$. However, even if the number of complications due to the $\mathrm{RH}$ had been underestimated in this study, the routinely use of CT scan would be unthinkable due to financial cost and the radiation risk. Another form of reasoning would be think that, if there is no presentation on plain thoracic radiography, there is no clinical manifestation and, consequently, no complication.

The primary indication for drainage was hemopneumothorax in 39 patients (65.0\%) corroborating previous findings ${ }^{12}$. Patients with hemothorax had a higher incidence of empyema (38.9\%) than those with isolated pneumothorax (33.3\%) or hemopneumothorax (30.8\%), which is quite reasonable since, in the former case, the risk to develop empyema is increased when blood accumulates in the pleural cavity, working as a culture medium for bacteria. 
Table 1 - Description of the patients with $\mathrm{RH}$.

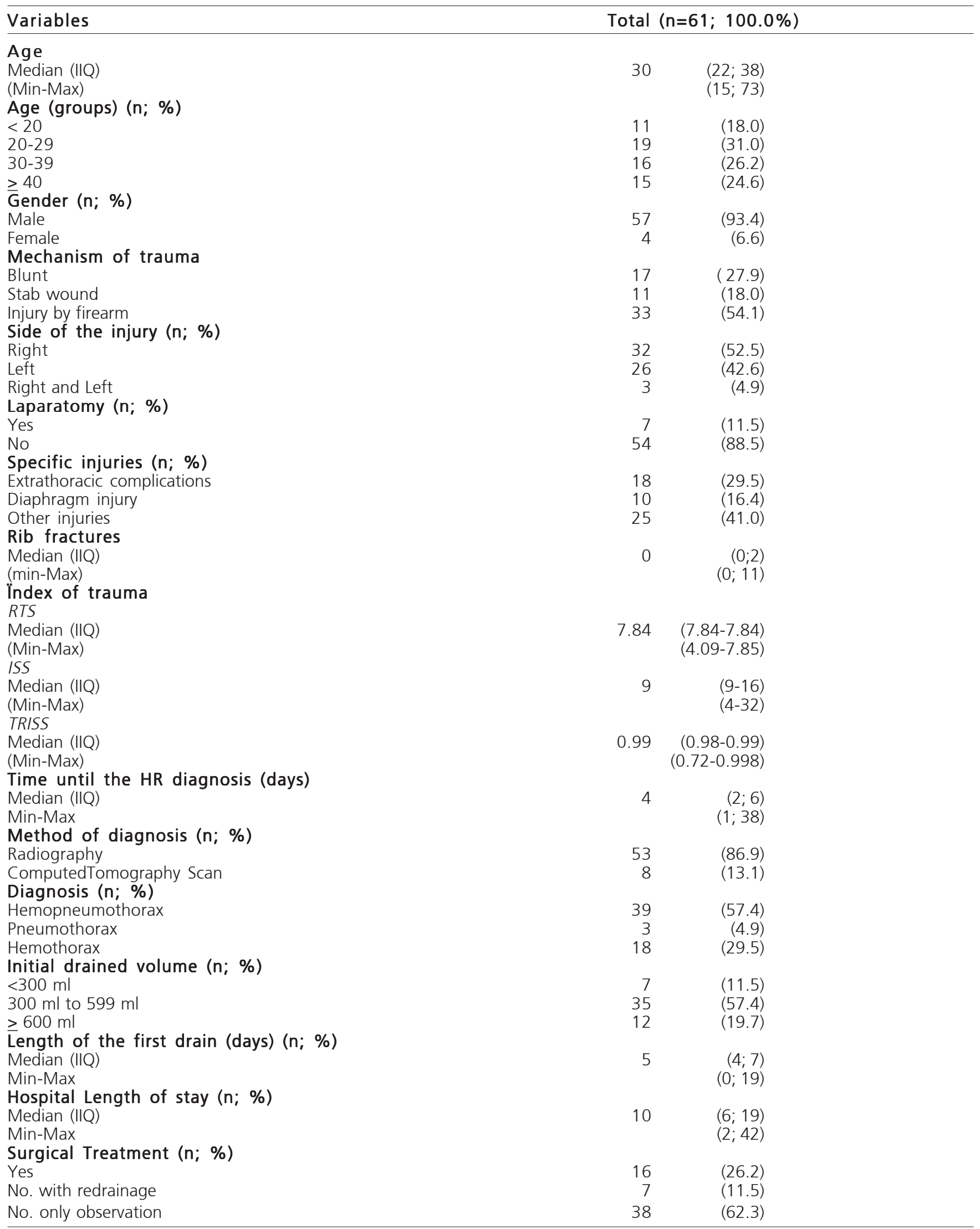

Source: HRTN (2009-2013) 
Table 2 - Empyema incidence in patients with $\mathrm{RH}$.

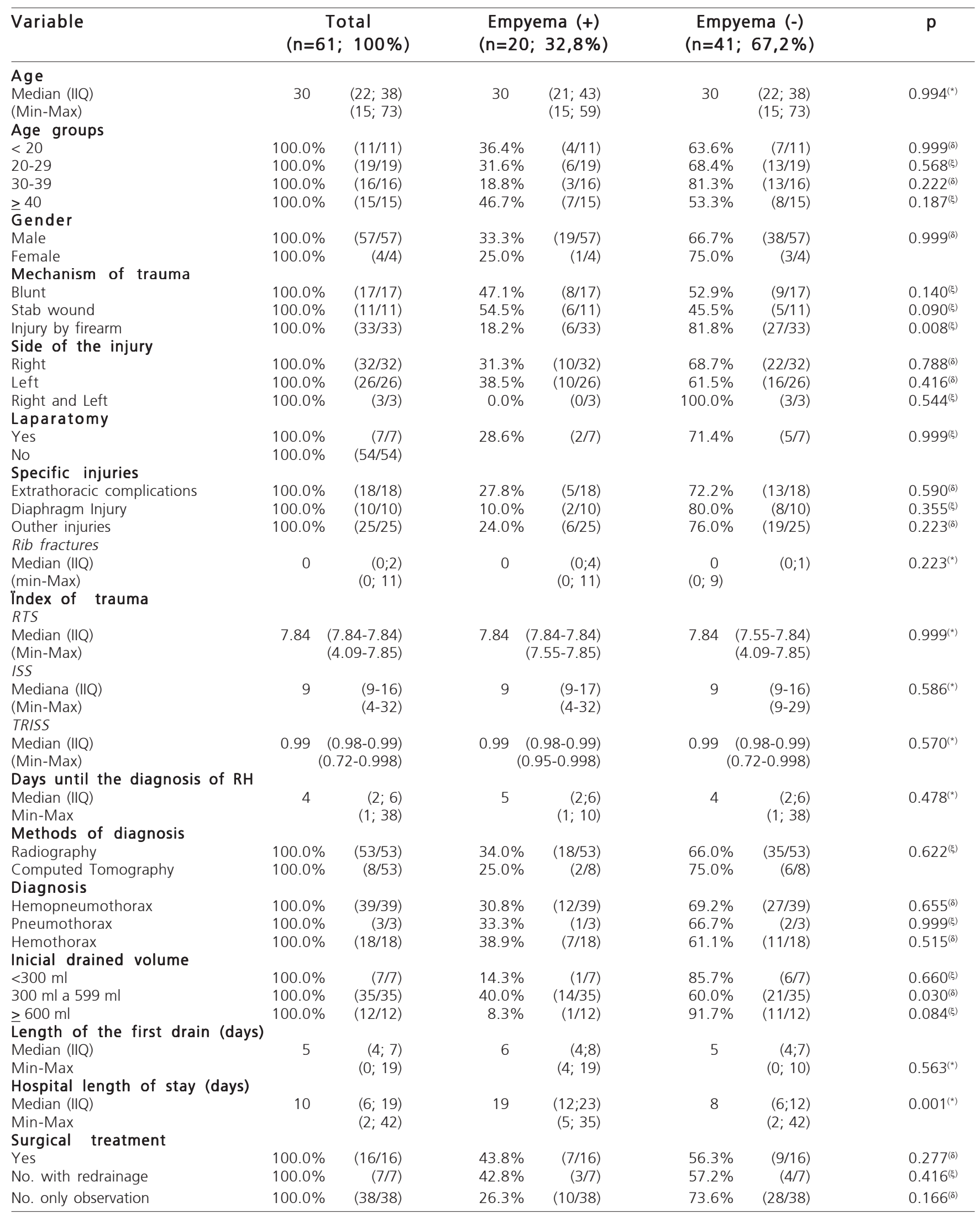

Source:HRTN (2009-2013)

Notes: (*) Mann-Whitney test,(ä) Fisher's exact test, (î) Pearson Chi-Square test. 
Regarding the initial volume drained, it seems reasonable and believable that the amount of blood at the first pleural drainage leads to the complications of $\mathrm{RH}$ and empyema, because liquid in high quantity in the peural cavity can accumulate instead to be drained. On the other hand, the increased liquid volume in the pleural cavity could also increase the drainage rate and thereby dragging the entire fluid to the drain, decreasing the amount of blood. Furthermore, the high drained volume may mean more severe trauma, meaning in fact, a greater number of associated lesions and increased risk of complications. The finding in this study is that the higher incidence of empyema occurred when the drained volumes ranged from 300-599 $\mathrm{mL}$, in addition of being the most commonly drained volume. It seems that this volume can be key reference for predicting complications such as empyema.

The median times, minimum and maximum stay of the drain were higher among patients with empyema, although not statistically significant. Empyema associated to longer time is expected, once the incidence of infection is increased after 72 hours of the drain insertion in the pleural cavity ${ }^{19}$. But the length of hospital stay was significantly higher among patients who developed empyema, which is predictable because, in the presence of complication, the patients have more suffering, besides an extended hospital staying and also, more costs to the patients, hospital and society itself.

Nearly two-thirds of the patients did not undergo any surgical procedure. Previous findings indicate success around $80 \%$ for observation of the $\mathrm{RH}^{8,12,17,20}$. In this study the lowest incidence of empyema was associated with observation (26.3\% versus $42.8 \%$ for redrenaige and $43.8 \%$ for surgical approach).

Among those without empyema, the difference among the three groups occurred in the mean of the hospital length of stay, having been progressively greater for those with surgery, followed by patients with redrainage, and finally to those without operation (results not shown). This could be explained by the attempt of frustrated nonoperative approach, plus the postoperative period.
These features with hospitalized patients could be allocated to other situations if prevention of $\mathrm{RH}$ had been done, and consequently reduction of empyema.

The small number of patients who developed empyema, irregular use of prophylaxis for other associated injuries, antibiotic treatment for other conditions may have influenced our results. Perhaps in the last one lies the biggest limitation of this study, which is the inability to evaluate the effect of antibiotic prophylaxis, once this one started to be routinely used after the start of the present study. Still, it draws attention to the high incidence of empyema, which could even be underestimated. Ultrasound was also not evaluated. Another interesting aspect would have been assessed the incidence of different complications for drainage in the operating room or in the emergency room. There was one single patient drained in the emergency room and this one had pneumonia and empyema. However, because only one case was done in this situation, it was not possible to establish the existence of any association between the occurrence of empyema and pleuropulmonary complication.

Little is known about the RH. Not long time ago, the rule for treatment of $\mathrm{RH}$ was conservative approach, and surgery was the exception. Lately, with the incorporation of new technologies, with low morbidity, it seems that the craving for surgical approach have been raised only to sort out problems in short time. Regarding the treatment of the diseases, morbidity and mortality must be considered according the risks to the patients. A proper recognition of the entity RH can clarify the need or not of surgical approach. Thus, future studies still need to be done.

The conclusions of this study are: the incidence of PD was $1.83 \%$ and $\mathrm{RH}$ was $10.63 \%$, these results are consistent with the low severity of the patients involved in this study and consistent with the literature. The incidence of empyema proved to be negatively associated with the occurrence of injury by firearms and positively associated with a drained volume between 300 and 599 ml, compared with lower or higher volumes.

\title{
R E S U M O
}

\begin{abstract}
Objetivo: analisar os fatores associados ao empiema em pacientes com hemotórax retido pós-traumático. Métodos: estudo prospectivo observacional. Os dados foram coletados de pacientes submetidos à drenagem pleural de emergência. Foram analisadas: idade, sexo, mecanismo de trauma, lado da lesão torácica, complicações intratorácicas decorrentes do hemotórax retido, laparotomia, lesões específicas, fratura de arcos costais, índices de trauma, dias até o diagnóstico, método diagnóstico do HR, indicação primária da drenagem pleural, volume inicial drenado, dias de permanência do primeiro dreno, procedimento cirúrgico. Obteve-se a incidencia acumulada de empiema, pneumonia e contusão pulmonar e a incidência de empiema em cada categoria das variaiveis analisadas. Resultados: a incidência acumulada de drenagem pleural por trauma foi 1,83\% e a de hemotórax retido entre aqueles com derrame pleural foi de 10,63\%. Houve 20 casos de empiema (32,8\%). A maioria tinha entre 20 e 29 anos, era do sexo masculino e sofreu ferimento por arma de fogo. A incidência de empiema entre pacientes com ferimento por arma de fogo foi inferior aos demais mecanismos; superior entre aqueles com volume drenado entre 300 e $599 \mathrm{ml}$. O tempo mediano de permanência hospitalar foi maior nos pacientes com empiema. Conclusão: as incidências de derrame pleural e hemotórax retido entre aqueles com DP nessa amostra de baixa gravidade dos pacientes foram, respectivamente, $1,83 \%$ e 10,63\%. A incidência de empiema revelou-se negativamente associada à ocorrência de ferimento por arma de fogo e positivamente associada a volume drenado entre 300 e $599 \mathrm{ml}$, bem como, ao tempo mediano de permanência hospitalar.
\end{abstract}

Descritores: Empiema. Traumatismos Torácicos. Tórax. Drenagens. Hemotórax. 


\section{REFERENCES}

1. Guimarães MB, Winckler DC, Rudnick NG, Breigeiron R. Análise crítica das toracotomias realizadas na sala de emergência durante 10 anos. Rev Col Bras Cir. 2014;41(4):263-6.

2. Kulshrestha P, Munshi I, Wait R. Profile of chest trauma in a leve I trauma center. J Trauma. 2004;57(3):576-81.

3. Khandhar SJ, Johnson SB, Calhoon JH. Overview of thoracic trauma in the United States. Thorac Surg Clin. 2007;17(1):1-9.

4. Meyer DM. Hemothorax related to trauma. Thorac Surg Clin. 2007;17(1):47-55.

5. Stewart RM, Corneille MG. Common complications following thoracic trauma: their prevention and treatment. Semin Thorac Cardiovasc Surg. 2008;20(1):69-71.

6. Smith RS, Fry WR, Tsoi EK, Morabito DJ, Koehler RH, Reinganum $\mathrm{SJ}$, et al. Preliminary report on videothoracoscopy in the evaluation and treatment of thoracic injury. Am J Surg. 1993;166(6):690-3; discussion 693-5.

7. Smith JW, Franklin GA, Harbrecht BG, Richardson JD. Early VATS for blunt chest trauma: a management technique underutilized by acute care surgeons. J Trauma. 2011;71(1):102-5; discussion 105-7.

8. DuBose J, Inaba K, Demetriades D, Scalea TM, O'Connor J, Menaker J, et al. Management of post-traumatic retained hemothorax: a prospective, observational, multicenter AAST study. J Trauma Acute Care Surg. 2012;72(1):11-22; discussion 22-4.

9. Heniford BT, Carrillo EH, Spain DA, Sosa JL, Fulton RL, Richardson JD. The role of thoracoscopy in the management of retained thoracic collections after trauma. Ann Thorac Surg. 1997;63(4):940-3.

10. Navsaria PH, Vogel RJ, Nicol AJ. Thoracoscopic evacuation of retained posttraumatic hemothorax. Ann Thorac Surg. 2004;78(1):282-5; discussion 285-6.

11. Meyer DM, Jessen ME, Wait MA, Estrera AS. Early evacuation of traumatic retained hemothoraces using thoracoscopy: a prospective, randomized trial. Ann Thorac Surg. 1997;64(5):1396400; discussion 1400-1.

12. DuBose J, Inaba K, Okoye O, Demetriades D, Scalea T, O'Connor $J$, et al. Development of posttraumatic empyema in patients with retained hemothorax: results of a prospective, observational AAST study. J Trauma Acute Care Surg. 2012;73(3):752-7.

13. Aguilar MM, Battistella FD, Owings JT, SU T. Posttraumatic empyema. Risk factor analysis. Arch Surg.1997;132(6):647-50; discussion 650-1.

14. Eddy AC, Luna GK, Copass M. Empyema thoracis in patients undergoing emergent closed tube thoracostomy for thoracic trauma. Am J Surg. 1989;157(5):494-7.
15. Thourani VH, Lancaster RT, Mansour KA, Miller JI Jr. Twenty-six years of experience with the modified eloesser flap. Ann Thorac Surg. 2003;76(2):401-5; discussion 405-6.

16. Dewan RK, Moodley L. Resurgence of therapeutically destitute tuberculosis: amalgamation of old and newer techniques. J Thorac Dis. 2014;6(3):196-201.

17. Rezende-Neto JB, Pastore Neto M, Hirano ES, Rizoli S, Nascimento Jr B, Fraga GP. Management of retained hemothoraces after chest tube thoracostomy for trauma. Rev Col Bras Cir. 2012;39(4):344-9.

18. Lima SO, Cabral FLD, Pinto Neto AF, Mesquita FNB, Feitosa MFG, Santana VR. Avaliação epidemiológica das vítimas de trauma abdominal submetidas ao tratamento cirúrgico. Rev Col Bras Cir. 2012;39(4):302-6.

19. Fontelles MJP, Mantovani M. Trauma torácico: fatores de risco de complicações pleuropulmonares pós-drenagem pleural fechada. Rev Col Bras Cir. 2000;27(6):400-7.

20. Coselli JS, Mattox KL, Beall AC Jr. Reevaluation of early evacuation of clotted hemothorax. Am J Surg. 1984;148(6):786-90.

21. Maloney JV Jr. The conservative management of traumatic hemothorax. Am J Surg. 1957;93(4):533-9.

22. Carreiro PRL, Drumond DAF, Starling SV, Moritz M, Ladeira RM. Implantação de um registro de trauma em um hospital público brasileiro: os primeiros 1000 pacientes. Rev Col Bras Cir. 2014;41(4):251-5.

23. Eren S, Esme H, Sehitogullari A, Durkan A. The risk factors and management of posttraumatic empyema in trauma patients. Injury. 2008;39(1):44-9.

24. Menger R, Telford G, Kim P, Bergey MR, Foreman J, Sarani B, et al. Complications following thoracic trauma managed with tube thoracostomy. Injury. 2012:43(1):46-50.

25. Fernandes TM, Dorigatti AE, Pereira BMT, Cruvinel Neto J, Zago TM, Fraga GP. Tratamento não operatório de lesão esplênica grau IV é seguro usando-se rígido protocolo. Rev Col Bras Cir. 2013;40(4):323-9.

Received on 10/01/2015

Accepted for publication 26/03/2015

Conflict of interest: none.

Source of funding: none.

Address for correspondence:

Mário Pastore Neto

E-mail: mariopastoreneto@gmail.com 